一技術報告一

バイオガソリン中の ETBE を指標としたガソリンの流通経路の絞込みに関する検証

吉田 浩陽, 鈴木 真一

科学警察研究所

テ277-0882 千葉県柏市柏の葉 6-3-1

\title{
Evaluation of ETBE in Biogasoline as a Marker for Tracking Distribution Routes of Gasoline
}

\author{
Hiroaki Yoshida and Shinichi Suzuki \\ National Research Institute of Police Science \\ 6-3-1 Kashiwanoha, Kashiwa, Chiba 277-0882, Japan
}

(Received 21 May 2008; accepted 1 October 2008)

\begin{abstract}
Biogasoline, which contains 7 vol\% of bio-ETBE (ethyl $t$-butyl ether), began circulating in the Metropolitan area of Japan on April 27, 2007. Among 44,000 gas stations in Japan, biogasoline is currently sold only in 100 gas stations. Name and location of these 100 gas stations are disclosed. If biogasoline is truly sold only in these gas stations, tracking a gasoline sample back to its retailer will be possible; when ETBE is detected in a gasoline sample, it is certain that the sample was sold in one of the 100 gas stations. Biogasoline was collected in the end of June, September, December 2007 and March 2008 from gas stations of 3 different brands in Chiba prefecture, and its color, density, composition and concentration of ETBE were analyzed. Regular gasoline was also collected from gas stations of the same 3 brands for comparison. GC/MS analysis revealed that biogasoline of 3 different brands was identical, suggesting that adulteration of biogasoline by mixing with regular gasoline was not carried out. ETBE was not detected from any sample of regular gasoline at all. Absence of ETBE in regular gasoline indicates that handling of biogasoline was strictly regulated, making the tracking of biogasoline sample back to its retailer possible.
\end{abstract}

Key words: Biogasoline, Bioethanol, ETBE, GC/MS

\author{
緒 言 \\ 2007年 4 月27日より，東京，神奈川，埼玉および \\ 千葉の 1 都 3 県の50箇所の給油所（ガソリンスタン \\ ド）においてバイオガソリンの試験販売が開始さ
}

れ，2008年度には販売給油所が 9 都府県の100箇所 に拡大された1).バイオガソリンの販売は, 2005年 に閣議決定された「京都議定書目標達成計画」の中 の「バイオマス由来の輸送用燃料導入への取り組み」 に基づくものである. バイオガソリンとは, 植物原 
料から得られたエタノール，すなわちバイオエタ ノールから合成したエチルターシャリブチルエーテ ル (ethyl $t$-butyl ether : ETBE) をレギュラーガソ リンに 7 体積パーセント添加したものである2).

ETBE はガソリンに添加する以外の用途には利用さ れていない.したがって，ガソリン中に ETBE が 検出された場合，それはバイオガソリンであるとほ ぼ断定できる．また，2008年度現在バイオガソリン を販売している100箇所の給油所の名称および住所 は石油連盟が公表している1).2008年 3 月末時点で 日本国内には抢よそ44,000箇所の給油所 ${ }^{3}$ がある が, 現状ではガソリンの効果的な異同識別法は存在 せず，販売給油所の絞込みは難しい. ETBE が検出 されれば，44,000店のうちわずか100店に絞り込む ことが可能であり, ガソリンの流通経路を絞り込む 指標としてのETBEの意義は大きい.

このように，ガソリン絡みの事案が発生した場 合，バイオガソリンは被疑者に結びつく有力な物的 証拠となりうるが，それは石油連盟の発表どおりに 100箇所の給油所でのみ販売されている場合に限ら れる. 他の給油所でも販売されている場合は絞り込 みに全く役立たない.ガソリンの流通経路は非常に 複雑で，いわゆる業転玉のように元売もしくは特約 店と小売店との間における売買契約上の正規の経路 を経ない商品も存在し, 流通過程で様々なメーカー のガソリンが混じる可能性がある4). バイオガソリ ンも例外ではなく, レギュラーガソリンと混合する 可能性があることを石油連盟が認めている5). 混合 した場合，100箇所のバイオガソリン販売給油所以 外でも ETBE を含むガソリンが販売される可能性 がある.この場合, 販売店の特定はほぼ不可能とな り, 流通経路を絞り込むための物的証拠としてのバ イオガソリンの価值は失われる.

そこで, 本研究では, バイオガソリンの物的証拠 としての能力を検証することを目的として，3 種類 のブランドのバイオガソリンとレギュラーガソリン を，2007年度に 3 ヶ月間隔で 1 年間にわたって収集 した. 収集した試料の色, 密度, 組成, ETBE 濃度 の分析括よび変性実験を行い，その結果からバイオ ガソリンの流通実態を推測し, バイオガソリン中の ETBE がガソリンの流通経路を絞り込む指標となり
うるか検証した。

\section{材料および方法}

\section{1 ガソリンの収集}

バイオガソリン : Fig. 1 の地図中の丸印は, 2007 年度時点で東京, 神奈川, 埼玉および千葉の 1 都 3 県に存在する50箇所のバイオガソリン販売給油所の 位置を示しているが，その内の矢印で示した千葉県 内の 3 箇所の各々異なるブランドの給油所から2007 年 6 月， 9 月，12月抢よび2008年 3 月末の同一日に 収集した。

レギュラーガソリン : Fig. 1 の地図中に星印で示 した 3 箇所の給油所から，2007年 7 月，10月，2008 年 1 月抒よび 4 月初めの同一日に收集した。この 3 箇所の給油所のブランドは，バイオガソリンを購入 した給油所と同じ 3 種類である. バイオガソリンを 購入した日のほぼ 1 週間後にレギュラーガソリンを 購入した。

バイオガソリンは，バイオ ETBE を含むレギュ ラーガソリンとの位置付けであり，バイオガソリン 販売給油所ではバイオガソリンを通常のレギュラー ガソリンの代わりに販売している. バイオガソリン とレギュラーガソリンの両方を 1 箇所の給油所で販 売しているのではないため, レギュラーガソリンは 別の給油所で購入しなければならない.

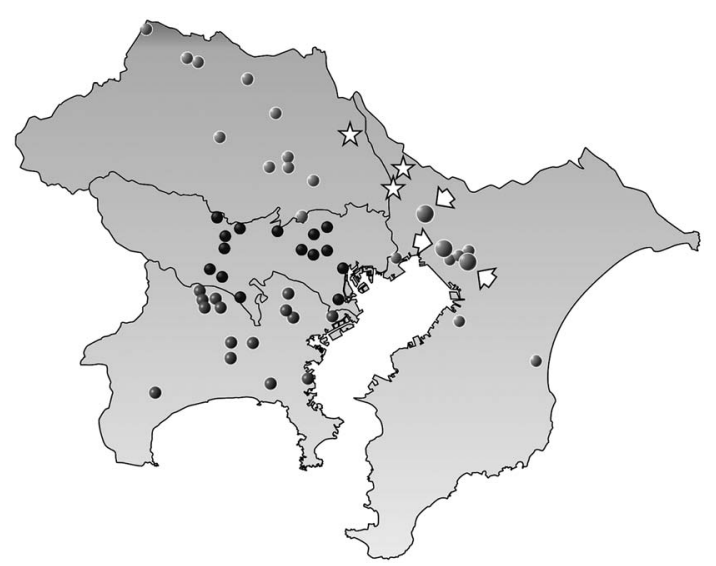

Fig. 1 Map of biogasoline stations. Biogasoline was collected from gas stations pointed by arrows. Regular gasoline was collected from gas stations indicated by stars. 


\section{2 試薬}

ETBE は東京化成工業の 1 級試薬（>95\% (GC) を用いた。

\section{3 ガスクロマトグラフィー/質量分析 (GC/MS)}

GC/MS は以下の条件で行った.

装置: Agilent Technologies 製6890N GC/5973N MSD

注入口温度 : $280^{\circ} \mathrm{C}$

スプリット比 $: 100: 1$

試料注入量 : $0.2 \mu \mathrm{L}$

カラム : J\&W Scientific 製 DB-5MS $(30 \mathrm{~m} \times 0.25$ $\mathrm{mm}$ i.d., 膜厚 $0.25 \mu \mathrm{m})$

カラム温度 : $40^{\circ} \mathrm{C}(5 \mathrm{~min})-15^{\circ} \mathrm{C} / \mathrm{min}-300^{\circ} \mathrm{C}$

移動相打よび流速 : $\mathrm{He}, 1 \mathrm{~mL} / \mathrm{min}$

インターフェース温度 : $260^{\circ} \mathrm{C}$

イオン化法 : EI

イオン源温度 : $230^{\circ} \mathrm{C}$

\section{1 外観}

\section{結果および考察}

Fig. 2 に収集したバイオガソリンおよびレギュ ラーガソリンの外観写真を示す。なお，収集したガ ソリンの 3 種類のブランドをそれぞれ $\mathrm{A}$ 社， $\mathrm{B}$ 社 および C 社とする。 また， 3 ヶ月毎に計 4 回収集し
ているが，それぞれ2007年 7 月 1 日，10月 1 日， 2008年 1 月 1 日および 4 月 1 日を挟んだ 1 週間の間 に収集しているため，收集時期を 7 月，10月，1月 および 4 月と表記する.

バイオガソリンは，同一日に収集したものについ て，3社間で色調の違いは見られない。但し，10月 分については，3 社間でわずかに色調が異なるよう にも見受けられる。 また, 收集時期が異なると, 色 調に若干の相違が見られる. 寸なわち 7 月および 10 月の試料は, 1 月抢よび 4 月の試料と比較してやや 登色がかっている。

一方，レギュラーガソリンは，同一日に収集した ものについて，ブランドが異なると色調が異なる. そのため, 色調によってブランドの推定が可能であ ると期待されるが，収集時期が異なると同じブラン ドでも色調が全く異なるため, 色調によるブランド の推定は不可能であることがわかる.

バイオガソリンは現在新日石の根岸製油所でのみ 製造されており，ガソリンスタンドのブランドが異 なっても供給元は同一である2). よって，3 社間で 色調の違いがほとんどないものと考えられる.しか し, 収集時期が異なると色調に相違が見られ, 同一 プラントで製造された製品でも時期によって色調が 変化することを示している.したがって，色調を元

\section{biogasoline}
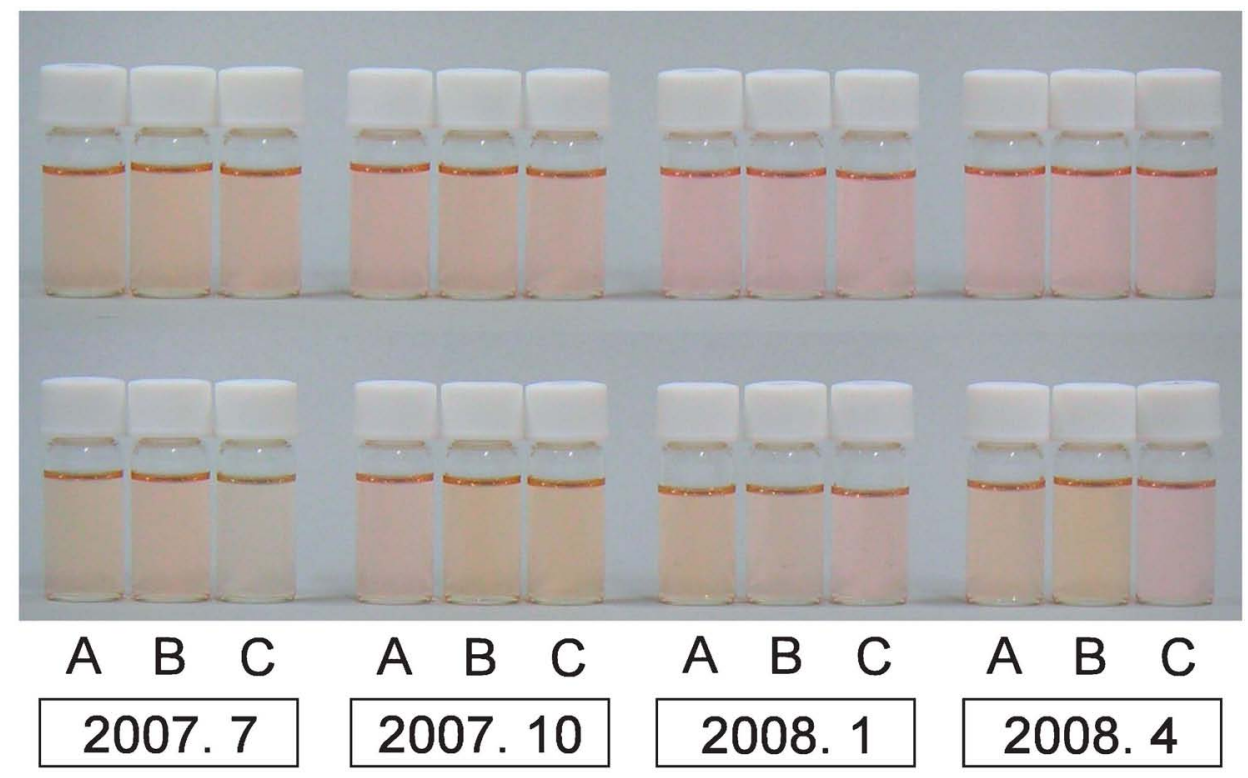

Fig. 2 Appearance of biogasoline and regular gasoline. 
に製造設備を同定するのは困難であると考えられ る.レギュラーガソリンは, 各々のブランドの元売 から供給されていると考えれば，色調に違いがある のは不思議ではないが，同じブランドでも時期が異 なると色調が大幅に異なる理由については, 製造時 期による色の違い, 元売間での製品の融通 ${ }^{4)}$, 業転 玉の販売など種々の可能性があり, 特定することが できない。

\section{2 密度}

収集したガソリンの一定量をホールピペットで量 り取り, 重量を測定して密度を求めた。結果を Table 1 に示す.

バイオガソリンは，同一日に収集したものは，3 社ともほぼ同一の密度であった，ただし，10月のB 社については, 他の 2 社との密度の差が若干大き い.

一方, レギュラーガソリンの密度はブランドによ って異なっていた。 また, 色と同様に, ブランド毎 に特定の傾向は見られなかった.

バイオガソリン, レギュラーガソリンともに, 各 々のブランドについて密度を時期毎に比較すると,

共通した傾向を有することがわかる，すなわち10月 の密度が最大で，以下 7 月，4月，1月の順に小さ くなっている. 製造時期は購入時期より前であるか ら，それぞれ9月，6月，3月抢よび12月中に製造 されたと考えると, 月平均気温が高くなるにつれ密 度が大きくなっていることがわかる，すなわち，製 品の製造時期の気温に応じて密度, すなわち組成が 調整されていることが明らかである.

\section{GC/MS による分析}

GC/MS を用いて収集したガソリンの組成を分析 した。収集した全 24 試料のトータルイオンクロマト

Table 1 Density of biogasoline and regular gasoline $(n=3)$.

\begin{tabular}{lccccccc}
\hline \multirow{2}{*}{ date } & \multicolumn{3}{c}{ biogasoline } & & \multicolumn{3}{c}{ regular gasoline } \\
\cline { 2 - 4 } \cline { 6 - 8 } & $\mathrm{A}$ & $\mathrm{B}$ & $\mathrm{C}$ & & $\mathrm{A}$ & $\mathrm{B}$ & $\mathrm{C}$ \\
\hline 2007. 7 & 0.722 & 0.721 & 0.721 & & 0.725 & 0.725 & 0.721 \\
2007. 10 & 0.723 & 0.725 & 0.723 & & 0.725 & 0.730 & 0.726 \\
2008. 1 & 0.713 & 0.714 & 0.713 & & 0.715 & 0.714 & 0.713 \\
2008. 4 & 0.715 & 0.715 & 0.714 & & 0.718 & 0.719 & 0.716 \\
\hline
\end{tabular}

グラム（TIC）を Fig. 3 に示す. なお，クロマトグ ラムの比較を可能にするため, トルエンのピーク高 さを同一に揃えて表示してある.

本分析条件では, ETBEのピークは保持時間 2.33 分に現れる。バイオガソリンは 12 試料全て ETBE のピークが観察されるが，レギュラーガソリンのク ロマトグラムにはETBEのピークが全く見られな い.よって，今回収集したレギュラーガソリン中に はETBEの混入，すなわちバイオガソリンの混入 はないことが明らかとなった。

また，同一時期に収集した 3 種類のブランドのバ イオガソリンのクロマトグラムを比較すると, 3 種 類ともピークパターン（ピークの位置, 本数抢よび 高さ）がほぼ等しい.よって，3 種類のブランドの スタンドで販売されているバイオガソリンの組成は ほぼ同一であるといえる，但し，10月は，Fig. 3 に aで示した範囲のピークに見られるとおり，A 社の ピーク高さが $\mathrm{B}$ 抢よび $\mathrm{C}$ 社と若干異なる.10月分 については, Fig. 2 に抢ける色調の違いおよび Table 1 における密度のばらつきが存在したが, TIC においてもこのようにブランド間の差異が認められ た。

ガソリンの組成を比較する場合は, 各々のクロマ トグラムを見比べてピークの有無および強度差を判 断するが，ガソリンの構成成分は極めて多いため判 定に手間がかかる。しかも，この方法では，個々の 成分の有無抢よび多鿒は分かるが，試料全体として の組成の差は把握し難い、試料の特徵を示すため に，幾つかの成分を抽出してその量を図式化するこ とがよく行われるが，ガソリンは成分が極めて多く またどの成分に差が生じるか予測できないため，こ の手法は適用できない.

そこで，クロマトグラム中に現れる全ての成分に ついて差異を可視化するために, 差分比クロマトグ ラムなる手法を以下の式により定義して用いた.

$$
\text { difference ratio }=\frac{\Delta I}{I}=\frac{I_{1}(t)-I_{2}(t)}{S M A L L\left(I_{1}(t), I_{2}(t)\right)}
$$

$\operatorname{SMALL}(A, B)$ は, $A, B$ のつの值のうち小さ い值を返す関数である. 本法では，比較する $2 つ の$ 試料のクロマトグラムについて，ある保持時間 $t$ に おける一方の試料のピーク高さ $I_{1}(t)$ を，もう一方 


\section{biogasoline}

A

'07. 7

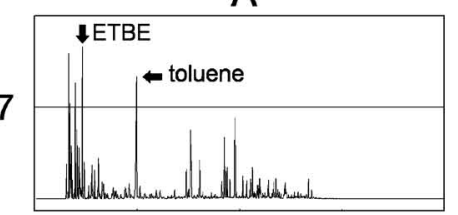

'07.10

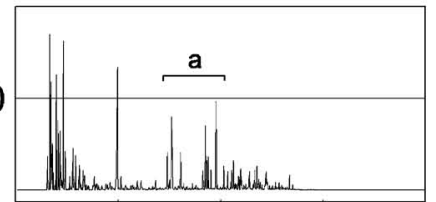

'08. 1

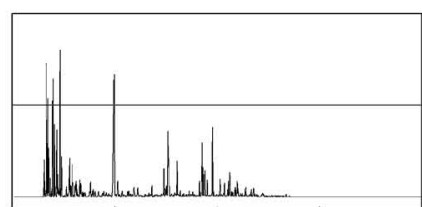

'08. 4

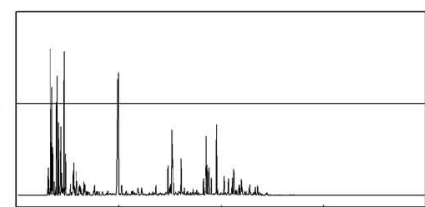

'07. 7

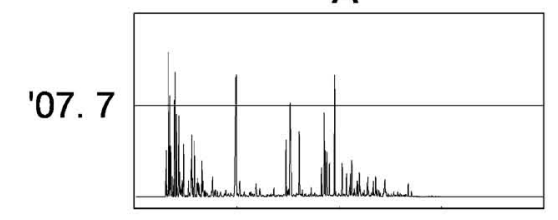

A
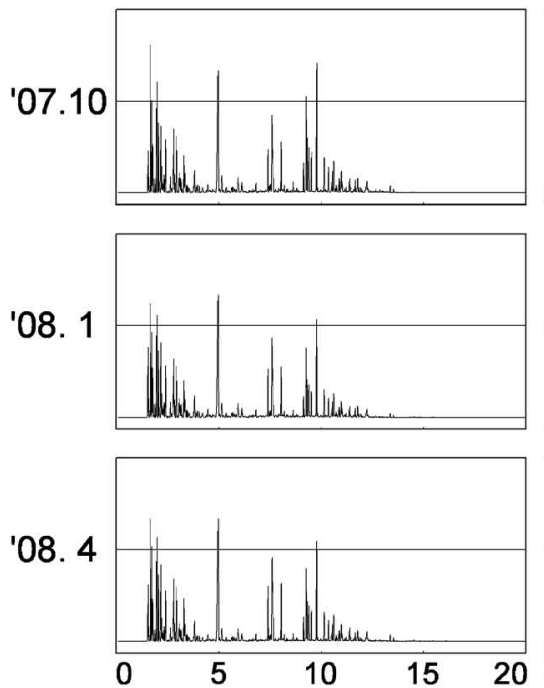

B
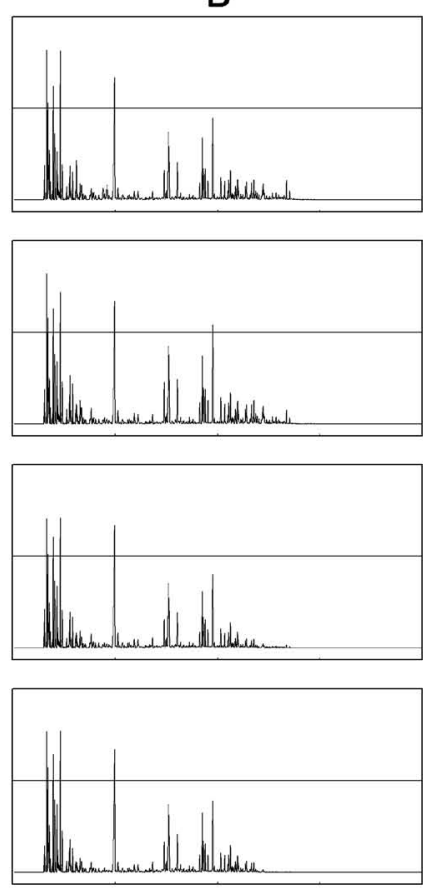

regular gasoline

B


C
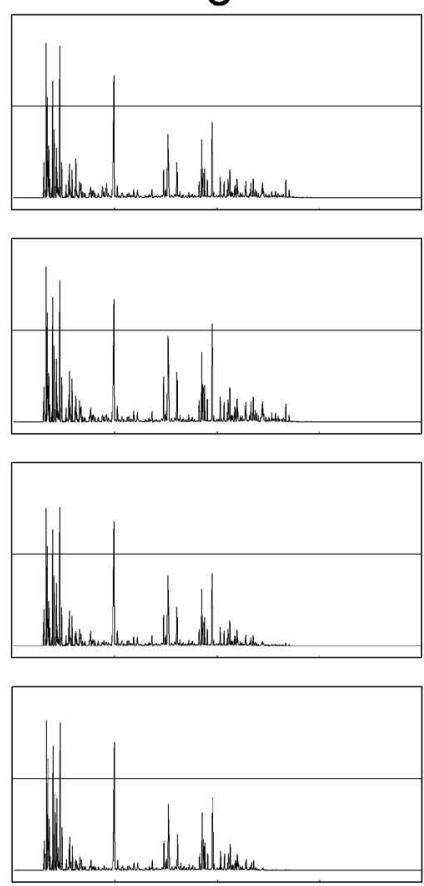

C
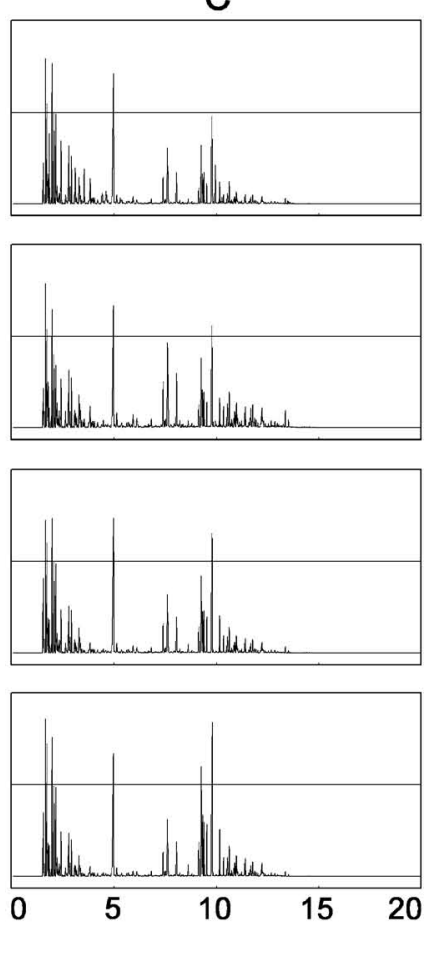

Fig. 3 Total ion chromatograms of biogasoline and regular gasoline. 


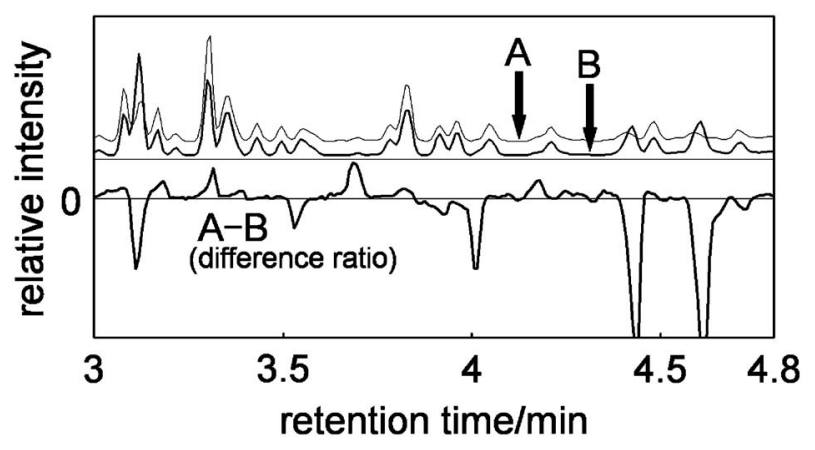

Fig. 4 Difference ratio chromatogram of $\mathrm{A}$ and $\mathrm{B}$ collected in 2007.7. TIC of A and B are also shown.

の試料における同じ保持時間 $t$ のピーク高さ $I_{2}(t)$ から減算する．この操作をクロマトグラム中の全て のデータポイントについて行うことで，すべての ピークについて差を求めることが可能である。しか し，単純に差を取るだけでは，低いピークの差が高 いピークの差よりも小さくなる傾向があり，公平な 評価ができない，そこで，求めた高さの差をピーク 高さで除して比を取ることで，ピーク高さの影響を 除いた。な掞，低い方のピーク高さを基準にして比 を求めるために，2つのクロマトグラムのうちの小 さい值を SMALL 関数で選択している.

2007年 7 月の A 社と B 社の差分比クロマトグラ ムの拡大図を，A 社と B 社の TIC と共に Fig. 4 に 示す，差を取る祭に，引かれた試料（A 社）にの み含まれる成分もしくはより多く含まれる成分は正 の值，引いた試料（B 社）にのみ含まれる成分もし くはより多く含まれる成分は負の值を示すのが見て 取れる。

Fig. 5 に収集した全試料の差分比クロマトグラム を示す，組成の差が一目で把握可能である．なお， 図中で $\mathrm{t}$ と示されたピークはトルエンのピーク形状 の差異に由来するもので，成分の差を示しているも のではない，本分析条件ではトルエンのピークはフ ロンティングする．測定毎にフロンティング部分の ピーク形状は変化するため，その変化が差分比クロ マトグラムに現れている.

バイオガソリンは，Fig. 5 中に I 〜 N で示すピー ク以外には組成の差がほぼ認められない，Nはフタ ル酸ジブチルであるが，I，II およびIII同定でき
なかったＩおよびIはブタンよりも保持時間が短 く，また $\mathrm{N}$ は $\mathrm{C} 4$ アルキルナフタレンよりも保持時 間が長い。しかも $\mathbb{N}$ は可塑剂であることから，これ らはガソリンそのものに由来するピークではなく， 流通過程において何らかの要因で混入したものと考 えられる.したがって，バイオガソリンはブランド が異なってもほぼ同一の組成であるが，ガソリン以 外の成分の比較によりスタンドの識別が可能な場合 があることが判明した。 また，10月分のバイオガソ リンは色調, 密度および TICに拈いて若干差異が 認められ，その原因としてレギュラーガソリンの混 入もしくはバイオガソリンのロットの違いが考えら れるが，差分比クロマトグラムでは而㧍よび $\mathrm{N}$ 以外 には差がほぼ認められなかった。レギュラーガソリ ンは Fig. 5 のように差分比クロマトグラムでの違 いが著しいため，レギュラーガソリンが混入した場 合は差分比クロマトグラム上で大きな差異が現れる 可能性が高い。よって，レギュラーガソリンが混入 している可能性は低いと思われる．色調などに見ら れる若干の差異は，おそらく在庫の回転の差などに 由来するのではないかと考えられる。

レギュラーガソリンは，Fig. 5 より明らかなよう に，ブランドによって組成が全く異なる。 また，収 集時期が異なると差分比クロマトグラムのパターン が全く異なることから，時期による組成の変化は規 則的なものではなくランダムであることが分かる.

したがって，ガソリンがどのスタンドで販売された かの異同識別を行うことは可能であるが，ブランド の推定は困難であると思われる.

\section{ETBE 濃度の定量}

今回収集したバイオガソリン中の ETBE 濃度 を，GC/MS を用いて標準添加法により求めた。正 確な濃度を求める場合は公定法6)に依らなければな らないが，公定法ではガソリン中の全成分のピーク 面積を求める必要があり煩雑である。また，今回収 集したバイオガソリンは，ブランドによる組成の違 いが認められず，ETBEの濃度も等しいと考えられ ることから，ブランド毎に濃度を決定する必要もな いが，バイオガソリンとレギュラーガソリンが混合 された場合を想定し，ETBE 濃度を簡易的に求める 方法を検討した。 
biogasoline



$\underline{\text { regular gasoline }}$
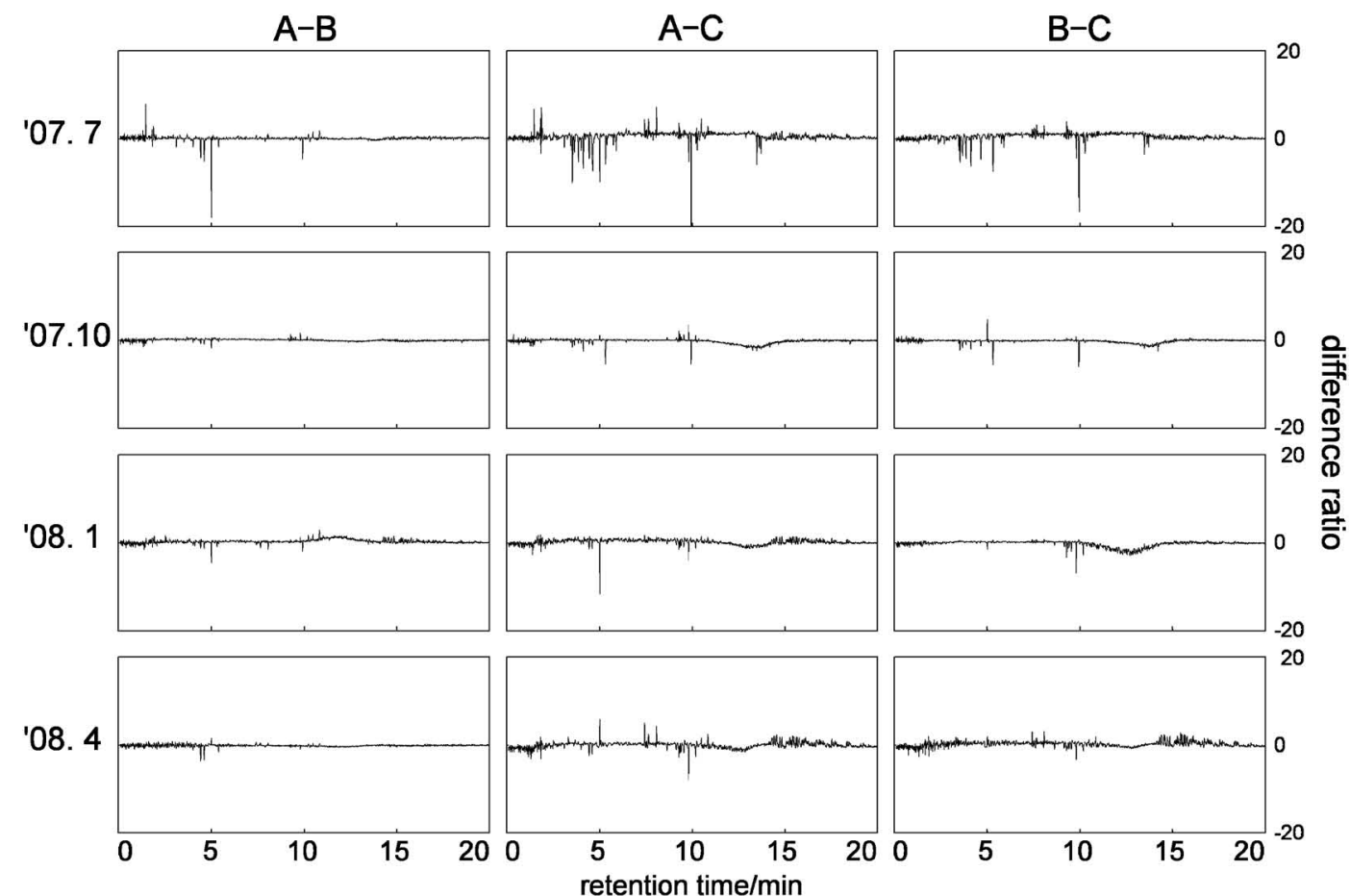

Fig. 5 Difference ratio chromatograms of biogasoline and regular gasoline.

Fig. 6 に，A 社の 7 月のガソリンの検量線を示 す。横軸は添加したETBEの体積百分率, 縦軸は $m / z 84$ のマスクロマトグラムにおけるETBEの面
積と， $m / z 91$ のマスクロマトグラムに抢けるトル エンの面積との比である. 本測定では, 試料中に含 まれているトルエンを内部標準として用いた。バイ 
オガソリンにETBEを添加した場合, 検量線は直 線にならない。これはレギュラーガソリンに ETBE を添加した場合も同様であったことから，ETBEの 添加によってガソリンの組成が変化することで生じ る GC 注入口でのディスクリミネーションにより, ガソリン中の各成分のカラムへの導入量が変化する ことが原因と考えられる，そこで，ディスクリミ ネーションを抑制するため, GC 導入にパルスドス プリット法（スプリット比200：1）を用いた結果, 検量線は 2 次曲線でフィッティング可能なことが判 明し，ETBE 濃度を求めたところ，7.1体積\%と実 際に添加されている量とほぼ等しい結果が得られ た．本法では検量線が直線にならず，正確な濃度を 求めるには公定法を用いなければならないが，概略 の濃度を求めるには本法で問題ないと判断される.

\section{5 バイオガソリンの蒸発実験}


分中では沸点が低いものに属する。 そこで，バイオ

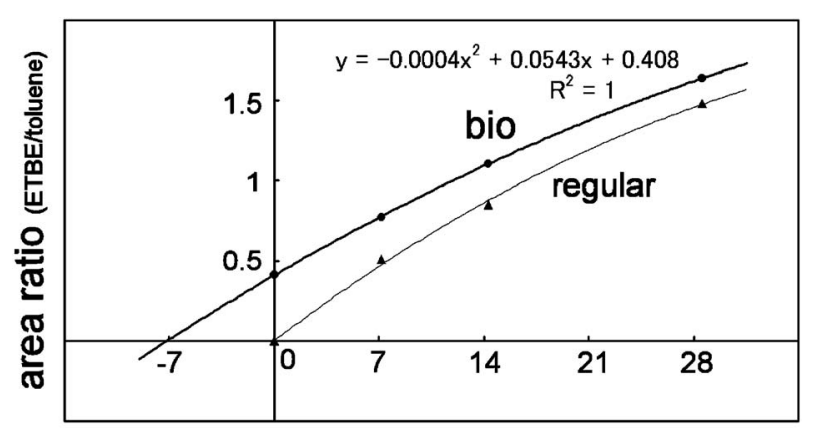

ETBE concentration/\%

Fig. 6 Titration curve of biogasoline A collected in 2007.7.
ガソリンが変性した場合に ETBE がどの程度揮発 して失われるか検証した。 バイオガソリンを常温常 圧下放置し，質量比で10\%から10\%きざみで90\%ま で蒸発させた試料を調製して GC/MS で測定し た。

Fig. 7 に，50および70質量％蒸発させたバイオガ ソリンのクロマトグラムを示す. 50\%未満の蒸発率 では, ETBEはクロマトグラム中で最も高いピーク を与える. 蒸発量が50\%を超えると, ETBEのピー クは急激に小さくなるが，元々バイオガソリンに含 まれているETBEの量が多いこともあり，70\%蒸 発させた試料のクロマトグラムにおいても ETBE のピークを容易に確認することが可能である． $80 \%$ 以上蒸発させるとETBEのピークは極めて小さく なり, クロマトグラムのバックグラウンドのレベル によっては検出が困難になると考えられる.

\section{結 語}

2007年から首都圈で販売が開始されたバイオガソ リンを収集してその性状を分析した。その結果，同 一時期に販売されているバイオガソリンの組成は, スタンドのブランドが異なっても同一であり, レギ ュラーガソリンへのETBE の混入も見られなかっ た、今回收集したスタンドは 3 箇所であるが，それ ぞれ異なるブランドのスタンドに拉いて同一のバイ オガソリンが販売されていたことから，バイオガソ リンの流通は厳密に管理されているといえる．この ことから, 少なくとも収集を行った時点, すなわち 2007年度は, バイオガソリンはバイオガソリン販売 スタンドでのみ販売されていると考えられることが

$70 \%$ evaporated biogasoline
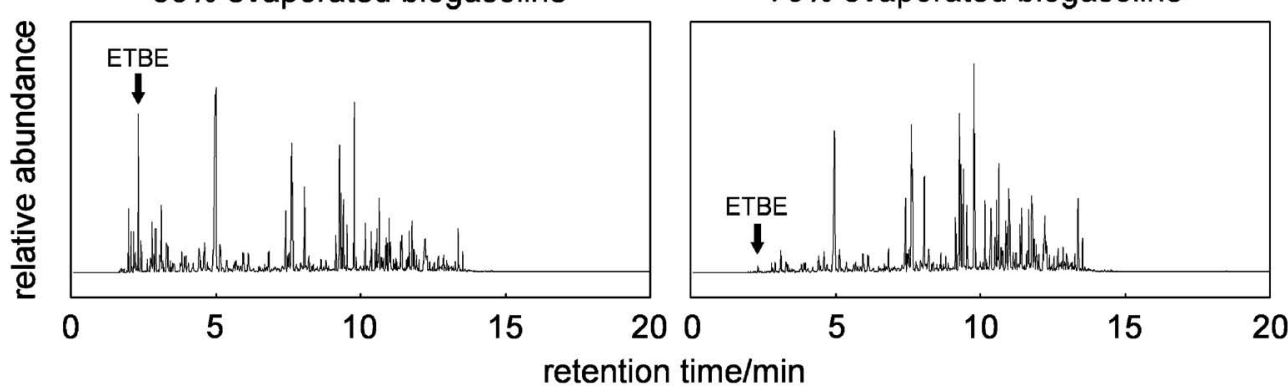

Fig. 7 Total ion chromatograms of 50\% and 70\% evaporated biogasoline. 
明らかとなった。これは，ガソリン中にETBEが 検出された場合，そのガソリンは50箇所のバイオガ ソリン販売スタンドのいずれかで販売された可能性 が高いとみなせ，入手ルートの絞込みに役立つこと を意味する．また，ETBE は沸点が低く揮発しやす いが，重量で半分以上蒸発したバイオガソリン中に も TICにて容易に確認可能な量が存在し，ある程 度変性した資料中からも検出可能であることが示さ れた。

2008年度はバイオガソリンの販売地域が 9 都府県 に拡大され，販売店は100店に増加した7)。この100 店の名称および住所は公表されている8 以降はさらに取扱スタンドを増やす計画が立てられ ており，どの時期までバイオガソリン販売スタンド 名の公表が続けられるのかは明らかではないが，現 在の流通実態を鑑みると，少なくとも試験販売期間 である2008年度内は, バイオガソリンはバイオガソ リン販売スタンドでのみ販売される可能性が高く, 入手経路の絞込みに有効であると考えられる.

\section{文 献}

1）石油連盟：バイオガソリンについて，http:// www.paj.gr.jp/eco/biogasoline/index.html.

2) 浜林郁郎：バイオガソリン（バイオ ETBE 配 合レギュラーガソリン）の供給開始. ペトロテッ ク, 30, 704-709 (2007).

$3 ）$ 全石連: 新着情報 $08 / 5$ 月, http://www.zensekiren.or.jp/02sintyaku/02.html.

4）公正取引委員会事務総局：ガソリンの流通実態 に関する調查報告書 (2004).

5) 石油連盟：バイオガソリン Q \& A, http: // www.paj.gr.jp / eco / biogasoline / qa_details_05. html\#Q3.

6）JIS K2536-2 石油製品一成分試験方法 第 2 部: ガスクロマトグラフによる全成分の求め方.

7）石油連盟：バイオガソリン取り扱いSS（サー ビスステーション）の追加について, http:// www.paj.gr.jp/paj_info/topics/2008/20080417. html.

8）石油連盟：バイオガソリン取り扱いSS（サー ビスステーション）の拡大について, http:// www.paj.gr.jp / paj_info / press / 2008 / 20080425. html. 